November 2007

\title{
Inter-ethnic Marriages, the Survival of Women, and the Logics of Genocide in Rwanda
}

Anuradha Chakravarty

Follow this and additional works at: https://digitalcommons.usf.edu/gsp

\section{Recommended Citation}

Chakravarty, Anuradha (2007) "Inter-ethnic Marriages, the Survival of Women, and the Logics of Genocide in Rwanda," Genocide Studies and Prevention: An International Journal: Vol. 2: Iss. 3: Article 4.

Available at: https://digitalcommons.usf.edu/gsp/vol2/iss3/4

This Articles is brought to you for free and open access by the Open Access Journals at Digital Commons @ University of South Florida. It has been accepted for inclusion in Genocide Studies and Prevention: An International Journal by an authorized editor of Digital Commons @ University of South Florida. For more information, please contact digitalcommons@usf.edu. 


\title{
Interethnic Marriages, the Survival of Women, and the Logics of Genocide in Rwanda
}

\author{
Anuradha Chakravarty \\ Department of Government, Cornell University
}

\begin{abstract}
This article focuses on the gendered dimensions of the genocide in Rwanda. It seeks to explain why Tutsi women married to Hutu men appeared to have better chances of survival than Tutsi women married to Tutsi men or even Hutu women married to Tutsi men. Based on data from a field site in southwest Rwanda, the findings and insights offered here draw on the gendered, racial, and operational dynamics of the genocide as it unfolded between April and July 1994.
\end{abstract}

\section{Introduction}

In September 1992, a military commission report in Rwanda officially defined the "main enemy" as "Tutsis from inside or outside the country" and the "secondary enemy" as "anyone providing any kind of assistance to the main enemy." Since the invasion of Rwandan Patriotic Front (RPF) rebels in 1990, extremist propaganda had focused on the immutable racial distinction between Hutu and Tutsi. The Tutsis were denounced as historic "invaders" who had "stolen the country." The RPF attack was cast as a similar attempt, undertaken with the help of Tutsis within Rwanda, all of whom were, by an extension of this racial logic, pronounced accomplices of the rebels. ${ }^{2}$

Despite this undifferentiated notion of "main enemy," not all Tutsis in a given area were targeted at the same time, or in similar ways, when the genocide began on the night of 6 April 1994. ${ }^{3}$ By the end of April, about half the Tutsi population had been killed, ${ }^{4}$ and Tutsi men and boys had been the primary targets. ${ }^{5}$ Several thousand Tutsi women and girls were killed in the first month of genocide, but it was from midMay onward that there was a significant rise in Tutsi female deaths. According to Alison Des Forges, it was likely that a "decision to kill women had been made at the national level and was being implemented in local communities." 6 By the time genocide was halted in mid-July, between 75 and $80 \%$ of the approximately 850,000 dead $^{7}$ were male. ${ }^{8}$ For this reason, Rwanda is sometimes referred to as the land of widows. ${ }^{9}$

There is a paucity of focused theoretical work or empirical research on the gendered dimensions of genocide in Rwanda. As a rule, scholarship on the genocide has focused on its multiple causes, evaluating the role of ethnic hatred and racial ideology vis-à-vis the role of fear, pressure, opportunism, and poverty; on the role of international actors; on the mechanisms and patterns of local participation; and on the diffusion of violence over time and space. ${ }^{10}$ Valuable information exists, however, in detailed reports prepared by human-rights organizations on sexual violence perpetrated against mainly Tutsi but also Hutu women, on the varied roles that women played as perpetrators of violence, and on estimates of the scale of rape, forced pregnancies, and the spread of HIV/AIDS. ${ }^{11}$

Anuradha Chakravarty, "Interethnic Marriages, the Survival of Women, and the Logics of Genocide in Rwanda," Genocide Studies and Prevention 2, 3 (November 2007): 235-248. (C) 2007 Genocide Studies and Prevention. doi: 10.3138/gsp.2.3.235 
Survivor testimonies and eyewitness accounts in the available literature suggest that while Tutsi women were not the primary targets in the early stages of the massacres, they were not treated in an undifferentiated manner. That is, Tutsi women married to Hutu men appear to have been targeted later than Tutsi women married to Tutsi men. It also appears that Tutsi women with Hutu husbands escaped death, rape, or mutilation more often than Tutsi women with Tutsi husbands. The paucity of large-scale systematic evidence, however, prohibits us from making conclusive or generalizable arguments from these observations.

Although the scope of this article is limited, in that the validity of these observations in a single research site cannot conclusively confirm that they hold true in a general sense across the country, a self-selection problem does not exist: Masaka sector in southwest Rwanda ${ }^{12}$ was chosen as a research site for entirely different reasons, such as proximity to a main highway and a local gacaca tribunal for genocide crimes that worked without frequent interruptions and down time. Both of these were important factors, because I was interested in investigating how knowledge about the genocide was produced at the local level through the operation of gacaca's judicial process, while the relative accessibility of Masaka sector made repeat visits and long-terms stays in the area possible. It was later that I discovered that Tutsi women married to Hutu men in Masaka sector had been more likely to survive genocide than Tutsi women married to Tutsi men.

It is worth noting that genocide was carried out at the local level with the widespread participation of local actors. Therefore, an intensive local-level investigation remains pertinent. This article goes beyond qualitative analysis and ethnographic empiricism to propose a theoretical explanation drawing on intersections of the gendered, racial, and operational logics of genocide in Rwanda.

In Masaka sector, of the twelve Tutsi female survivors who were adults in 1994, ten had been married to Hutu husbands. The other two had Tutsi husbands who were killed. Of all other mono-ethnic Tutsi marriages, both partners perished. Approximately seventeen Hutu women had been married to Tutsi men in 1994 . With one exception, all of the Tutsi husbands were killed.

At least three Tutsi men who were adults in 1994 survived the genocide in Masaka. Of these, one was an elderly man (married to a Hutu woman) who later died of natural causes, and the two others migrated out of the sector for work. During the period of field research, there were no adult Tutsi men living in the sector. About ten Tutsi children survived in 1994. Of these survivors who were not adults in 1994, the majority are female. Except for one young man who now lives elsewhere, the others are now young adolescents or in their late teens. Since ethnicity passes down the male line in Rwanda, all of them had Tutsi fathers. But none of their fathers survived the genocide. $^{13}$

I spent several months in Masaka sector, living with ordinary residents and participating in everyday life. The data for this article are drawn from in-depth interviews with a representative sample of the population and from transcripts of eight complete trials for genocide crimes observed at the local gacaca tribunal. ${ }^{14}$ The accounts given here are reconstructions of events such as the genocide in Masaka-the data were gathered from different sources and verified for accuracy by means of cross-checking against other available information. In certain places, the narratives of respondents are reproduced in their own words. Because of space constraints, other accounts have been condensed and narrated in the third person to highlight those details that are relevant for this analysis. 


\section{A Three-Pronged Explanation}

Any satisfactory explanation has to go beyond blanket theses such as ethnic hatred and genocide ideology, because these cannot account for variation in the way Tutsis were targeted or explain why all Hutus did not participate in the killings. ${ }^{15}$ In the following subsection, gendered practices of nationalist or identity-based violence are examined in order to explain why Tutsi men were primarily targeted in the initial stages and why it was so difficult for Tutsi males of all ages to survive. The next subsection shows how gendered constructions of the ethnic "other" help to explain why Tutsi women were allowed to survive in much higher numbers than male Tutsis. This, however, does not explain why Tutsi women with Hutu husbands were relatively safe from physical harm compared to Tutsi women married to Tutsi men. The succeeding subsection argues that the operational dynamics of genocide at the local level offer a plausible explanation. The last two subsections explore how this intersection of racial, gendered, and operational logics of genocide explains the experiences of Hutu women in interethnic and mono-ethnic marriages.

\section{Targeting Tutsi Men}

Adam Jones has argued that mass killing of men has been a "definitional feature" of genocide and often a "prelude to the 'root and branch' extermination" of a community. ${ }^{16}$ The reasons for targeting the male population might be the strategic need to destroy battle-age male non-combatants capable of joining the ranks of enemy soldiers or to eliminate social elites capable of mobilizing resistance (church leaders, opinion leaders, and politicians being predominantly male in general). The use of sexual violence against men makes it possible to inflict humiliation by feminizing the ethnic "other"17; the physical extermination of men can be used, in combination with other methods, to prevent a community from perpetuating itself.

It is not difficult to find confirming evidence in the case of Rwanda. In the numerous small-scale massacres of Tutsis during the years of civil war preceding the genocide, Tutsi men were almost exclusively targeted as potential members of the RPF. ${ }^{18}$ Besides killing Tutsi men during the genocide, the perpetrators also castrated Tutsi male children, sometimes forced adult Tutsi men to have sex with known HIV-positive women, ${ }^{19}$ and spared neither the very old nor the very young. ${ }^{20}$ Because Tutsi men were rarely spared, they were not in a position (in reality, not alive) to cajole or bargain with perpetrators for the lives of their Tutsi wives or children.

\section{Targeting Tutsi Women: Gendered Constructions of the "Other"}

The racialization of identity in Rwanda can be traced to the early twentieth century. Colonial authorities interpreted pre-existing social inequalities in light of the Hamitic hypothesis (the idea that Tutsis were racially similar to the Europeans and, thus, allegedly superior to the Negroid Hutu in physiology, intellect, and innate abilities). Following this logic, the Belgians introduced a race-based census and ethnic identification cards. Hitherto salient markers of identity such as lineage, clan, and dialect were gradually subsumed under a racial understanding of social difference, ${ }^{21}$ and, in the pre-independence era, both Hutu and Tutsi elites appropriated those elements of the Hamitic hypothesis that best suited their interests. ${ }^{22}$ The Bahutu Manifesto, which foreshadowed the establishment of the First Hutu Republic, pointedly stated that the social problem was the racial problem and should be understood as the political, economic, and cultural domination of the Tutsi race. From 1990 onward, the extremist media popularized the same logic, harping on the 
"origins of the criminality of Tutsi" 23 and calling on "all Hutu to reinforce their unity." 24

Decades of institutionalized racism had produced mental maps of racial difference, concomitant with myths about origins, stereotypes about the "nature of the Tutsi" and the "nature of the Hutu," 25 and imputation of a historic agenda of conquest by Tutsi as a race. The extremist media-Radio-Télévision Libre des Milles Collines (RTLM) and the magazine Kangura-represented the Tutsi as an ambitious, ruthless, and tricky race. Tutsi women in particular were portrayed in an array of forms. Historically perceived as women of the royal courts or the upper classes, they were cast as exotic sexual objects beyond the reach of the ordinary Hutu. If a Tutsi woman deigned to marry a Hutu man, it was said to be a conspiracy of her male co-ethnics to use her feminine charms to trick Hutu men. During the genocide, Hutu males were targeted for propaganda and innuendo suggesting that they could now enjoy these exotic and arrogant Tutsi women, provided they were perpetually on guard against their treacherous nature. It is interesting that there were no specific orders for rape, nor were lists compiled of those to be raped (unlike the lists that were drawn up of those marked for death); nevertheless, innuendo, jokes, and propaganda were interpreted as intended. ${ }^{26}$

It was standard practice for female Tutsis to be allowed to live and be abused as sex slaves, either by force or by a mutual compact that traded sexual services for survival. It is also true, though, that thousands of female Tutsis were raped before being killed. The word kubohoza ("to liberate") was used for the act of rape. This word had been used in the context of the launch of multi-party politics in 1991 that marked the end of President Juvénal Habyarimana's single-party dictatorship of the National Republican Movement for Democracy and Development (MRND) party. At that time it referred to a violent campaign by the Democratic Republican Movement (MDR) party that forced MRND officials to switch their political affiliation to the MDR. ${ }^{27}$ It was also associated with the coercive appropriation of land and resources and reflected a tendency to use violence in the pursuit of political ends. The use of the same word for rape indicates that sexual violence and forcible impregnation were consciously associated with politics and the extremist Hutu Power agenda. ${ }^{28}$ (Here it is worth noting that feminist scholars have shown how rape and impregnation of enemy women is part of war and an attempt at ethnic cleansing. ${ }^{29}$ In the former Yugoslavia, for example, raped women were kept in custody until they could no longer abort, and similar stories spread in both Serbia and Croatia about how "'others' had raped 'our' women, and wanted to spoil our nation."30)

\section{Tutsi Women in Interethnic Marriages}

To argue that Hutu men were not targeted and were therefore able to protect their Tutsi wives would be to obscure the complex reality of genocide. Many ordinary Hutus were specifically singled out for violence, including old enemies of locally powerful génocidaires, social deviants such as thieves and sorcerers, ${ }^{31}$ and sometimes the rich. Hutu men married to Tutsi women were also vulnerable targets because of the social construction of female Tutsis as spies for their male co-ethnics. The first of the "Hutu Ten Commandments" printed in the extremist magazine Kangura announced that any Hutu man who had a Tutsi female as wife, mistress, secretary, or even friend would be considered a traitor. ${ }^{32}$ As a result, a Tutsi wife could become a source of embarrassment, if not a deadly liability, for a Hutu man among his co-ethnics and the focal point for considerable pressure from Hutu family members who felt 
unsafe harboring an icyitso ("accomplice"). In fact, many Hutu husbands abandoned their Tutsi wives or handed them over to their killers without protest. Tellingly, in Nazi Germany in the 1930s, Christian husbands were similarly pressured to divorce Jewish wives and divorce cases were on the rise. ${ }^{33}$

Although interethnic marriages had traditionally been a way of cementing ties and building relationships based on mutual exchange between Hutu and Tutsi families, the institution was subject to intense scrutiny in the genocidal propaganda. Radical nationalist projects derive legitimacy from focusing on questions of racial purity, origin, and genealogy, where blood and semen are the pure fluids that transmit racial belonging, moral purity, and spiritual integrity; if contaminated, they are believed to transmit disease and decay. ${ }^{34}$ The fear of interethnic marriages stemmed from concerns about destruction of the nation through the racially impure progeny of mixed couples. There was also paranoia about the danger posed by an "elusive enemy" who could not be identified, despite being among them, because the differences were supposedly biological and "hidden"-not cultural, linguistic, or even physiological in any obvious fashion. ${ }^{35}$ Warnings such as "Tutsi, don't try to hide yourselves" appeared in issues of Kangura as early as the winter of 1990/1991, referring to Tutsis figuratively as hiding behind their Hutu spouses but also directed metaphorically at ibiymanyi (those of mixed parentage). ${ }^{36}$

All Hutu men in mixed marriages could not save their Tutsi wives, but those able to do so were successful, in large part, because of the operational logic of genocide at ground level. Recent research has shown how ordinary people in Rwanda were mobilized by local networks of family, friends, and peers to join groups of attackers through a mix of coercion and persuasion. ${ }^{37}$ The mobs were large, the most common size of a group ranging between eleven and thirty people. ${ }^{38}$ In Masaka sector, there was a smaller core group whose members split up and mobilized larger groups for different attacks.

From my interviews with Hutu men who were able to save their Tutsi wives from rape or death, what stands out prominently is the fact that they were acquainted with one or more of the people at the center of the attack. This allowed them to negotiate and strike a bargain with the mob, usually involving the exchange of a cow or other livestock or property for the life of the woman. Even if the Hutu husband did not recognize anyone in the mob, a bargain was possible if a friend or neighbor who rallied around the besieged family happened to know one or more of the key actors among the attackers and stepped in to mediate.

The lives of Tutsi men were rarely spared. Thus, in mono-ethnic Tutsi marriages, the Tutsi husband was not in a position either to save himself or to protect his wife. In Masaka, the usual practice was for the death squads to grab the family's livestock; steal bricks, tiles, and furniture from the house; and kill the couple and the children after ascertaining that there were no further assets that had been hidden away. Families split up and went into hiding, each member on his or her own, to maximize chances of survival. If someone was discovered, attackers coerced information about the location of the livestock and other property owned by the family-and then, having verified that the things were truly where he or she said they were, killed the victim. ${ }^{39}$

In contrast, a deal between Hutu men with Tutsi wives and Hutu perpetrators was still possible, particularly if three conditions were fulfilled: first, one or more of the key actors in the mob happened to be acquainted with the Hutu husband or with someone who supported the husband's position; second, the Hutu husband was on the spot when the attack occurred; and, third, he was willing to take risks. It must 
be understood that each argument with an armed and hostile mob constituted a risk, and each insistent plea for reconsideration meant that the Hutu husband was courting danger and risked being physically assaulted, if not killed.

Still other elements went into making such a compact between Hutu men durable. If the Hutu protector happened to be a man who was well respected or well liked in the community, the bargain was sealed with the attackers' promise, on their word of honor, that they would not renege on the deal. The situation changed dramatically if a Hutu man hid his Tutsi wife in the bush, or in someone else's home, and she happened to be discovered. It was unlikely that her Hutu hosts would risk the ire of the mob by attempting to negotiate or resist. If the hosts did not personally know anyone involved in the attack, there was also little possibility of bargaining to spare the woman's life. In the event that the hosts did resist, they were usually threatened and sometimes beaten up. If the Tutsi woman was found hiding alone in the bush, she could be raped or killed immediately.

\section{Hutu Women in Interethnic Marriages}

The above account provides evidence that Tutsi men could not protect themselves, as they were denied a chance to bargain for their lives. Neither could Hutu wives of Tutsi men do much to protect their husbands, because there were no readily available templates for such social roles of women as negotiating partners with men. Rwandan men expected their women to be hardworking and submissive, and women traditionally had little access to education, jobs, or inheritance or ownership rights to property. ${ }^{40}$ In Masaka, not only were the Tutsi husbands and children killed, their houses were also destroyed and property looted.

Hutu women in interethnic marriages were also perceived as traitors and were often raped or beaten up as punishment by male co-ethnics. Nationalist projects depend on maintaining the boundaries of "their" nation. This requires constant policing and tight control of women's sexuality, marriage, and reproduction-whether in Rwanda, in the former Yugoslavia, or in Nazi Germany. ${ }^{41}$ Serb and Croat women in mixed marriages bore the brunt of Serb and Croat nationalisms, respectively: Serb women married to Croat men suffered insults thrown at them by ethnic Serbs, such as "Croatian prostitutes" or "Ustaša mothers"; Croat women married to Serb men were called such names as "Serbian prostitutes" and "Četnik mothers" by ethnic Croatians. ${ }^{42}$ In Nazi Germany, non-Jewish women guilty of "racial misconduct" under the Nuremberg Laws were photographed and their names and addresses publicly displayed. Because male Jews were portrayed as sexual predators in Nazi discourse, most cases dealing with "race defilement" laws involved Jewish men and non-Jewish women. 43

\section{Hutu Women in Mono-ethnic Marriages}

Like every other social actor, Hutu women with Hutu husbands largely failed to extend support or comfort to Tutsi women faced with grave danger. Recent advances in feminist theory alert us to the risks of simplistic and essentialized notions of "sisterhood" and "women's solidarity" across ethnic and class divides. On the one hand, there are often real ideological or political differences between identity-based groups or class formations, and the real question for women may well be how they can bridge these differences without denying them. On the other hand, women may be too invested or rooted in these positions to shift or move across the chasm to locate common interests and build on them. ${ }^{44}$ 
Feminist analyses show how women are both mobilized and oppressed by their "own" nationalist movements, which glorify traditional gender codes and male power. ${ }^{45}$ Jean Bethke Elshtain argues that by slipping into idealized roles such as the "spartan mother" or the "beautiful soul," women have "more often than not" exhorted their men to violence in the national interest and honored them for their actions. ${ }^{46}$ Expected to be patriotic and comforting wives, German Christian women provided a soothing family environment for their men to come home to from their jobs in the concentration camps and did not confront them with questions about the war, the Jews, or politics in general-even when they heard rumors or knew from different sources about what was going on. ${ }^{47}$ In Rwanda, the extremist magazine Kangura conferred upon Hutu women the dubious distinction of being "more suitable and more conscientious in their roles as woman, spouse and mother" and urged them to wean Hutu men away from the charms of Tutsi women. ${ }^{48}$ The emotional insecurity and envy this induced may have prevented Hutu women from feeling more sympathetic toward the plight of Tutsi women. In fact, many Hutu women played an active part in the genocide. They refused refuge to Tutsis in need, betrayed those hidden in their homes, acted as informants, and also killed. As loyal Hutus, some prominent Hutu women donned military fatigues and organized the massacres in their areas. ${ }^{49}$ The example of Masaka sector cautions against over-generalization in any direction. Sometimes polygamous Hutu men hid the Tutsi wife in the home of the Hutu wife. Perhaps these women were motivated by genuine sympathy for the plight of the Tutsi wives, or perhaps they did not want to incur their husband's displeasure and submitted to his wish that they extend refuge. In Masaka, at any rate, among the surviving Tutsi women married to Hutu men, it was rare to encounter a case where they attributed their survival primarily to being hidden in the Hutu wife's home.

\section{Genocide in Masaka Sector}

There is little evidence that all perpetrators were motivated by a genocidal impulse, but it would be problematic to underestimate the extent of fear and paranoia that ordinary Hutu felt toward the ethnic "other" as a whole in the context of the RPF invasion and the unflagging hysteria broadcast over the RTLM. Tutsi residents of Masaka were suspected of secretly harboring sympathy for the rebels. A few Tutsi individuals were singled out, and rumors began to circulate about their allegedly active support for the military effort of the RPF. One of them, John, had become the object of much speculation. During my interviews, many respondents mentioned that people used to say that John hated Hutus. Many had apparently believed that documents proving his support to the rebels had been found and that John was expecting to be rewarded with political office after the RPF victory.

With the introduction of multi-party politics in 1991, various political parties had organized meetings in Biryogo, a trading center an hour's journey by foot from Masaka. The MDR party had enjoyed a popular resurgence in this area because of its status as the party of the founding father of the first Hutu Republic and its association with the Hutu of the south. Some young men from Masaka had been sent to a neighboring district for military training. Respondents said they discovered only later that these people had been trained as Interahamwe, the feared youth militia. ${ }^{50}$

Most people clearly recalled an incident they identified as the first act of genocide in the area. The night of 6 April had been a tense one for the community. They had heard of the assassination of President Habyarimana on the radio, and the newscast 
had held the RPF responsible. In the early hours of 7 April, a Tutsi businessman who lived in Biryogo was killed.

That morning some people came to our sector from Biryogo saying that Michel had been killed. They were looking for John because they said he was helping the Inkotanyi. ${ }^{51}$ We had been sitting in Alex's bar at the gasantere. They informed us that people were taking beans, sugar, and other things from Michel's shop and many people from here went to see what they could take. ${ }^{52}$

The gasantere came up as a recurrent motif in peoples' narratives in the interviews and also in their testimonies at the gacaca tribunal. Gasantere are spaces at the heart of community life at the grassroots level. ${ }^{53}$ Within the gasantere there are bars serving alcohol and meat, small shops, and a weekly market attracting local farmers and sellers from the nearest trading center. These centers became places where local strongmen orchestrating the killings met with ordinary perpetrators. Some meetings were restricted to an inner circle, whose members were well known in Masaka for their high visibility during the genocide and their leadership of mob attacks at multiple sites in the sector. Other meetings were open to the public, and people would drift in and out.

Information was pooled about the number of Tutsis killed and how many remained. People vied for the leaders' attention and provided information about possible hiding places of fugitives. The leaders divided those who gathered around them (in bars and other meeting places) into groups and sent them on specific missions. ${ }^{54}$ Sometimes a mob from another sector would venture into Masaka, merge with the local groups if they happened to meet on the hills, and go on an attack together. ${ }^{55}$ In the evening, stolen cows or goats would be slaughtered and the gasantere became sites for feasting and swapping stories about the day's events. On the aforementioned day, news about Michel's death had spread quickly as people returned home with the looted items.

It was Thursday. Around noon, the old woman came to my house. She said, "my child, our time has come"... They hid in the sorghum fields that night. ${ }^{56}$

"The old woman" referred to was an elderly Tutsi woman who had a Tutsi husband and a large family. The family lived near the interviewee. Except for one daughter, Odette, everybody had gone to hide in the bush that night. Odette's mutilated body, with her breasts cut off, was discovered the next morning:

I had heard loud noises and people were shouting as they went by on this road but it was dark. I did not know who they were. The family returned the next morning and they called us after finding her body. Some of us helped to bury her. ${ }^{57}$

Christopher Taylor has argued that techniques of cruelty derived from a meaningful "mythic logic" in which Tutsi were thought of as a harmful "blockage" requiring excision from the body politic to restore the nation to health. The racial logic had been organically mapped onto concepts of sickness (blockage) and health (restoration of flow) in traditional medicine. Victims were thrown into rivers, as if to represent the flowing out of impurity, and the dead were piled up in pit latrines as if the nation had relieved itself of bodily wastes. Breast oblation of Tutsi women and castration of Tutsi men symbolically represented attempts to "block" the flow of bodily fluids necessary to reproduce and sustain life. ${ }^{58}$

For the vast majority of people in Masaka, it was several days before they realized that Tutsi were the intended targets. Initially, both Hutu and Tutsi had been afraid of 
spending nights at home and went to hide in the fields. The morning of 8 April was described as follows:

There had been attacks during the night in other cells also but nobody was killed there... We saw that only homes of Tutsi were burning... Our cows had been stolen. Next morning, I got information about who had taken our cows. We went there and got many of our cows back. ${ }^{59}$

Neither was there much awareness, in those first few days, that the violence had been set in motion by government leaders at the highest level and that government offices were not going to be sanctuaries for the Tutsi. Tutsis who managed to survive the roadblocks and get to the district office were killed there. ${ }^{60}$

We had gone to inform the conseiller about Odette's death, but he was having many problems dealing with the situation. The homes of his neighbors were burning. He told us to go to the district to get help. ${ }^{61}$

Many Tutsis had died in Masaka by the time the weekend was over. Mono-ethnic Tutsi families had been targeted first. As mentioned above, families often split up to maximize their chances of survival and went into hiding separately. Those who were found were killed. Interethnic couples in which the husband was Tutsi were also attacked, and the husband and Tutsi children were killed. Tutsi wives of Hutu husbands were hunted last.

Many Hutu respondents said that they understood after this that "Tutsi had been given up to be killed," meaning not so much that the government had ordered the killings but that the government would do nothing to step in and prevent Tutsis from being killed. They did not deny the involvement of local residents but blamed unemployed youth and soldiers from "elsewhere," as well as death squads from neighboring sectors, for the actual killings. However, based on information pieced together from trial testimonies at the gacaca proceedings, it appears that the initial attacks were orchestrated by core groups that were highly mobile and were trained and equipped for killing. These key actors successfully activated their local networks, attracted a mass following by providing ample opportunities for plunder, and coerced the unwilling. There was often overlapping membership across various groups. But when they went on attacks together, peer pressure and common experiences of brutality forged a similar mindset and a certain loyalty to the squad. For instance, the vocabularies of participants in the attacks reveal the use of hunting metaphors to refer to search-and-kill operations. ${ }^{62}$

\section{Stories of Survival}

In this section, the experiences of two Tutsi women married to Hutu men will be discussed. Jill did not survive the genocide, and the account of her death contrasts sharply with the story of Chantal's narrow escape.

Chantal had worked out a routine. She would hide in the bush during the day and slip back, under cover of darkness, to spend the night at home with her husband, Paul, and their children. One night they heard the shouts of an approaching mob. Paul urged Chantal to slip away through the back door and hide in the sorghum fields. The stalks of sorghum were several feet tall and provided reasonably good cover in the dark. The attackers demanded that Chantal be turned over to them, but Paul responded that she had run away weeks ago and was probably dead by now. They refused to believe the story and searched the entire house. They held machetes at the throats of the children and threatened to kill them if Paul did not tell them 
about Chantal's whereabouts. Among those leading the attack were a few people that Paul knew well; he had often shared drinks with them and visited their homes in the past. These people insisted they had a reliable tip that Chantal was alive and was being hidden by her husband. Paul began to bargain for a settlement at this point.

Roused by the shouts and the cries, a Hutu neighbor came up to the house and supported Paul's plea that the mob take the only cow the family owned and spare Chantal's life. This neighbor also knew the leaders of the group. It came out during the gacaca trials that he had participated in other attacks with these very same people, and that was how he knew them-but at the time, it was fortunate for Paul that the neighbor stepped up to bargain on his behalf with the mob. The two men demanded a guarantee that the mob would not renege on their agreement and return to kill Chantal later. The leaders pledged in writing that because Paul had "only one person who was Tutsi-the wife," and because this "Tutsi bears children who are Hutu," $" 63$ they would not attack his house. They also promised on their word of honor to prevent other groups from targeting the couple.

Jill was not so fortunate. Her husband had hidden her in the home of his trusted Hutu friends in another cell. She had been hiding in the space between the roof and a room's ceiling with her child for several weeks. The first group that attacked the home of her elderly Hutu hosts said that they had been informed about an icyitso (accomplice) hiding there, but they did not discover her up in the roof space. The Hutu hosts said they suspected that one of Jill's neighbors had seen her at their home and tipped off the attackers. Jill and her child were discovered during the second search of the house a few days later.

Jill's husband used to scout around the area looking out for attackers. It is not clear whether someone had identified him; some of the attackers discovered him and hit him with the blunt edge of a machete. The bulk of that mob came from a neighboring sector, and neither Jill's husband nor the Hutu hosts knew the leaders of the attack. The child ran to the father, and the two escaped. Jill was killed immediately in the front yard, and her hosts buried her nearby. Some attackers pursued the father and child but could not find them. The child remained with an old Hutu woman until July.

The chances of escaping rape or death shrank dramatically if the intended victims were discovered and did not have a Hutu protector present who not only had some degree of familiarity with the leaders of the mob but was also willing to take some personal risks in the victims' defense. Tutsi women were saved when their Hutu husbands were tipped off about impending attacks by reliable friends who were in cahoots with other perpetrators or when Hutu husbands were able to procure Hutu identity cards through powerful contacts in the area or to negotiate a deal that might preserve the lives not only of their Tutsi wives but also of other Tutsi relatives for at least another day.

When all other inducements failed, the argument remained that Tutsi women married to Hutu men gave birth to Hutu children. Early in the genocide, an elderly Hutu man saved the lives of two young nieces, daughters of his Hutu sister who had married a Tutsi man. The husband had been killed, but the old man intervened and argued that the lives of the girls should be spared because they would grow up to be the wives of Hutu men. The leader of this mob was related to the old man. Unconvinced that the disheveled children were indeed girls, the attackers demanded that they strip so they could be sure the argument was reasonable. As the naked 
children cowered on the floor in a kneeling position, the old man argued and reasoned until the attackers finally left. He then dug a deep trench in his banana plantation, where he hid and fed the girls until the genocide came to an end three months later.

\section{Concluding Notes}

This article has tried to cover considerable ground using a three-pronged explanation drawing on the racial, gendered, and operational dynamics of genocide in Rwanda. There is a great need to focus on the experiences of victims, survivors, and perpetrators as gendered actors. People depended on each other for survival in complicated waysthe specifics of the situation when faced with a death squad, prior relationships and mutual understandings among Hutu and between Hutu and Tutsi during such interactions-and each situation was always mediated by gender considerations.

\section{Notes}

1. Prosecutor v. Bizimungu et al., Indictment, ICTR-2000-56-I (25 September 2002), para. 4.6.

2. “Si le FPR gagnait, qui protégerait le peuple majoritaire?” Kangura 55 (January 1994), cited in Jean-Pierre Chrétien, Jean-François Dupaquier, Marcel Kabanda, and Joseph Ngarambe with Reporters Sans Frontières, Rwanda: les médias du génocide (Paris: Karthala, 2002), 118.

3. Linda Melvern, Conspiracy to Murder: The Rwandan Genocide (London: Verso, 2004), 164. Within hours of the assassination of President Juvénal Habyarimana, there were killings in places such as Gisenyi and Kigali. According to Christian Davenport and Allan Stam, GenoDynamics: Understanding Genocide through Time and Space, http:// www.genodynamics.com (accessed 3 August 2007), the genocide began in "three major locations: the middle of the country (Kigali Rural), Southwest (Cyangugu), and Northwest Rwanda (Gisenyi). Immediately following the onset of the genocide, the killings spread to two larger locations in the West (Kibuye) and in the capital city (Kigali). In the initial three areas, violent activity increases. This pattern continues until April 12th, when the killings begin to extend outside the capital, maintaining a presence in West. By the 19th, murders in Kibuye prefecture decrease and those from the city of Kigali begin move towards Southern Rwanda."

4. Alison L. Des Forges, "Leave None to Tell the Story": Genocide in Rwanda (New York: Human Rights Watch, 1999).

5. African Rights, Rwanda: Death, Despair and Defiance (London: African Rights, 1995), xxiii.

6. Des Forges, Leave None to Tell, 296.

7. Gérard Prunier, The Rwanda Crisis: History of a Genocide (New York: Columbia University Press, 1995), 265. According to Prunier, about 800,000 Tutsis and 30,000 moderate Hutus were killed; he estimates that about 130,000 Tutsis survived the genocide. Estimates of genocide casualties are contested and range from a conservative 500,000 dead to calculations in excess of one million dead.

8. Gendercide Watch, "Case Study: Genocide in Rwanda 1994," http://www.gendercide.org/ case_rwanda.html (accessed 3 August 2007).

9. Claire Chavroche, Terre des veuves: journal du Rwanda (Paris: L'Harmattan, 2001).

10. Scott Straus, The Order of Genocide: Race, Power and War in Rwanda. (Ithaca, NY: Cornell University Press, 2006); Lee Ann Fujii, "The Power of Local Ties" (paper presented at APSA annual meeting, Philadelphia, 31 August 2006); Philip Verwimp, "An Economic Profile of Peasant Perpetrators of Genocide: Micro-Level Evidence from Rwanda," Journal of Development Economics 77 (2005): 297-323; Peter Uvin, "Ethnicity and Power in Rwanda and Burundi: Different Paths to Mass Violence," Comparative Politics 31 (1999): 253-71; René Lemarchand, "Rwanda: The Rationality of Genocide," Issue: A Journal of Opinion 23, 2 (1995): 8-11; Alan J. Kuperman, 
"Provoking Genocide: A Revised History of the Rwandan Patriotic Front," Journal of Genocide Research 6 (2004): 61-84; Christopher C. Taylor, Sacrifice as Terror: The Rwandan Genocide of 1994 (Oxford: Berg, 1999); Jean Hatzfeld, Une saison de machettes. Récits (Paris: Seuil, 2003). For a roadmap of research priorities on the Rwandan Genocide see Timothy Longman, "Placing Genocide in Context: Research Priorities for the Rwandan Genocide," Journal of Genocide Research 6 (2004): 29-45.

11. Binaifer Nowrojee, Shattered Lives: Sexual Violence during the Rwandan Genocide and Its Aftermath (New York: Human Rights Watch, 1996); Rwanda: Broken Bodies, Torn Spirits: Living with Genocide, Rape and HIV-AIDS (London: African Rights, 2004); Not So Innocent: When Women Become Killers (London: African Rights, 1995). Numerous reports are also available from Rwandan NGOs and from genocide widows' and survivors' organizations.

12. All place names and peoples' names have been changed to ensure anonymity.

13. These figures are culled from reports available at the sector and in each of the cells (smallest administrative units) within the sector and from interviews with survivors (including Hutu genocide widows), local gacaca tribunal judges, and other residents of Masaka. The figures were verified by the local representative of IBUKA, the umbrella genocide survivors' organization in Rwanda; she lived in Masaka, and, although she did not maintain lists of names, she knew each of these people well. Having lived in the homes of local residents of Masaka for several months, I believe these figures are highly accurate.

14. Interviews were conducted in Kinyarwanda and translated into English by a multilingual interpreter. Gacaca used to be an ad hoc customary institution at the grassroots. Elders or other trusted individuals acted as mediators between parties to a conflict. For a variety of reasons, including the need to expedite the cases of at least 120,000 people accused of genocide crimes (some estimates put the caseload at 400,000 people awaiting trial as of 2005), gacaca was reinvented by state law, and judges elected from the largely peasant population were trained in the law. The work of these local tribunals depends on the active participation of the population in the form of testimony and confessions. See, e.g., William A. Schabas, "Genocide Trials and Gacaca Courts," Journal of International Criminal Justice 3 (2005): 879-95.

15. African Rights, Rwanda: Tribute to Courage (London: African Rights, 2002); Penal Reform International [PRI], The Righteous: Between Oblivion and Reconciliation? (Kigali: PRI, 2004). Scott Straus, "How Many Perpetrators Were There in the Rwandan Genocide? An Estimate," Journal of Genocide Research 6 (2004): 85-98. According to Straus, the perpetrator population is about 200,000.

16. Adam Jones, "Gendercide and Genocide," Journal of Genocide Research 2 (2000): 185-211, 198, 201.

17. Dubravka Zarkov, "The Body of the Other Man: Sexual Violence and the Construction of Masculinity, Sexuality, and Ethnicity in Croatian Media," in Victims, Perpetrators, or Actors? Gender, Armed Conflict and Political Violence, ed. Caroline Moser and Fiona Clark, 69-82 (London: Zed Books, 2001).

18. Des Forges, Leave None to Tell.

19. African Rights, Broken Bodies, 19.

20. Jones integrates the positions of Leo Kuper and Steven Katz to argue that even without systematic violence against women and children of the ethnic "other," targeting a gender group (males) in whole or in substantial part for destruction is itself one of the more common forms of genocide. Jones, "Gendercide and Genocide," 199.

21. Nigel Eltringham, Accounting for Horror: Post-genocide Debates in Rwanda (London: Pluto, 2004), 19; see also Catharine Newbury, The Cohesion of Oppression: Clientship and Ethnicity in Rwanda, 1860-1960 (New York: Columbia University Press, 1988).

22. See Peter Uvin, Aiding Violence: The Development Enterprise in Rwanda (West Hartford, CT: Kumarian Press, 1998), 16-18. According to the Hamitic hypothesis, the Tutsis 
were a race of European extraction, possessing a superior intellect and an innate administrative ability that made them "natural" rulers.

23. Kangura 39, 14-19, cited in Chrétien et al., Les médias, 123 (my translation)

24. Kangura 6 (December 1990): 6-8, cited in Chrétien, Les médias, 141 (my translation).

25. In April 1999, the Catholic Church in Rwanda organized an in-house symposium that discussed, among other things, post-genocide ethnic relations. There was one session on the common stereotypes about essentialized characteristics of the "other" held by Rwandans. See Sinode igeze he mu madiyosezi yose [How Far Is the Synod in All Dioceses?] (report, 12-15 April 1999), 21-24.

26. African Rights, Not So Innocent, 44.

27. The First Republic had been a one-party state of the MDR. Habyarimana, who usurped power through a coup in 1973, also set up a one-party state and banned the MDR. His own party, the MRND, was dominated by the Hutu of the north. After the introduction of multi-party politics in 1991, the MDR made a quick comeback. Before the genocide began, however, the MDR and other parties split into moderate and extremist factions.

28. Nowrojee, Shattered Lives, n. 61.

29. Nickie Charles and Helen Hintjens, "Gender, Ethnicity and Cultural Identity: Women's 'Places," in Gender, Ethnicity and Political Ideologies, ed. Nickie Charles and Helen Hintjens, 1-26 (London: Routledge, 1998), 11.

30. Mirjana Morokvasic, "The Logics of Exclusion: Nationalism, Sexism and the Yugoslav War," in Gender, Ethnicity and Political Ideologies, ed. Nickie Charles and Helen Hintjens, 65-90 (London: Routledge, 1998), 80.

31. Interview respondents mentioned witnessing the death of a female sorcerer and her daughter. There were also incidents of murder of local troublemakers. There was some controversy in Masaka as to whether the (Hutu) widow of a (male Hutu) thief murdered during genocide should be considered a genocide survivor in the same way that Hutu widows of Tutsi men were commonly thought of as survivors.

32. Kangura 6 (December 1990), cited in Chrétien, Les médias, 141.

33. Sybil Milton, "Women and the Holocaust: The Case of German and German-Jewish Women," in Women and the Holocaust: Different Voices, ed. Carol Rittner and John K. Roth, 213-49 (New York: Paragon, 1993), 217; Jonathan C. Friedman, Speaking the Unspeakable: Essays on Sexuality, Gender and Holocaust Survivor Memory (Lanham, MD: University Press of America, 2002), 30.

34. Sarah Benton, "Founding Father and Earth Mothers: Women's Place at the 'Birth' of Nations," in Gender, Ethnicity and Political Ideologies, ed. Nickie Charles and Helen Hintjens, 27-45 (London: Routledge, 1998), 34.

35. Eltringham, Accounting for Horror, 23, cites Omer Bartov's concept of the "elusive enemy." Bartov writes of the Nazi regime, ". . as in all nightmares, this elusive enemy generated much greater anxiety than the easily identifiable one. The notion that the enemy is among us yet cannot be unmasked has always been the stuff of fear and paranoia and the cause of destructive imaginings and violent eruptions." Omer Bartov, "Defining Enemies, Making Victims: Germans, Jews, and the Holocaust," American Historical Review 103 (1998): 771-816, 780.

36. Kangura (March 1991), cited in Nigel Eltringham, Accounting for Horror, 23.

37. Charles K. Mironko, "Ibitero: Means and Motive in the Rwandan Genocide" (working paper, Yale Center for International and Area Studies, 2004); Straus, "How Many Perpetrators"; Fujii "Power of Local Ties."

38. Straus, "How Many Perpetrators," 92.

39. Masaka sector gacaca trials \#4 and \#6 (May-June 2005).

40. Nowrojee, Shattered Lives, n. 19.

41. In the discourse of French right-wing nationalism, "sexual metaphors are used... to warn about the vulnerability of the French nation to invasion and thereby destruction-mainly through a mixing of French women with "other men." Charles and Hintjens, "Gender, ethnicity," 10. 
42. Mirjana Morokvasic-Miller, "From Pillars of Yugoslavism to Targets of Violence: Interethnic Marriages in the Former Yugoslavia and Thereafter," in Sites of Violence: Gender and Conflict Zones, ed. Wenona Giles and Jennifer Hyndman, 134-51 (Berkeley: University of California Press, 2004), 144. The terms Ustaša and Četnik derive the names of a Nazi-controlled Croatian puppet government and a Serbian loyalist/antiCommunist guerrilla force known to have collaborated with the German occupiers during World War II, respectively. There are layers of meaning to the use of these terms, including both "enemy" - the Četniks and Ustašas fought each other during World War II-and "collaborator" (with the occupier).

43. Friedman, Speaking the Unspeakable, 29.

44. Nira Yuval-Davis, Gender and Nation (London: Sage, 1997); Cynthia Cockburn, The Space Between Us: Negotiating Gender and National Identities in Conflict (New York: St.

Martin's Press, 1998), 5; Lois A. West, Feminist Nationalism (New York: Routledge, 1997).

45. Wenona Giles and Jennifer Hyndman, "Gender and Conflict in a Global Context," in Sites of Violence: Gender and Conflict Zones, ed. Wenona Giles and Jennifer Hyndman, 3-23 (Berkeley: University of California Press, 2004), 9.

46. Jean Bethke Elshtain, "Thinking about Women and International Violence," in Women, Gender, and World Politics, ed. Peter R. Beckman and Francine D'Amico, 109-18 (Westport, CT: Bergin and Garvey, 1994), 109.

47. Gitta Sereny, "Into That Darkness," in Women and the Holocaust: Different Voices, ed. Carol Rittner and John K. Roth, 270-86 (New York: Paragon, 1993); Claudia Koonz, Mothers in the Fatherland: Women, the Family and Nazi Politics (London: Methuen, 1987).

48. "Voici les 10 Commandements," Kangura 6 (December 1990), cited in Chrétien, Les médias, 141 (my translation).

49. African Rights, Not So Innocent, 49-52.

50. The word interahamwe means "those who stand together" or "those who attack together." The Interahamwe was the youth militia of the MRND party.

51. Inkotanyi, meaning "tireless warriors," was the name by which the RPF referred to itself.

52. Interview \#48 (male Hutu). A random number has been assigned to each interview to ensure anonymity as far as possible.

53. The gasantere, or center for the sector, is usually in close proximity to the government office. Each cell or every two or three cells in the sector may have its own center.

54. Trial transcript \#4 (May 2005).

55. Trial transcript \#6 (June 2005).

56. Interview \#41 (female Hutu).

57. Interview \#32 (male Hutu).

58. Taylor, Sacrifice as Terror, ch. 3.

59. Interview \#39 (Hutu widow of Tutsi husband).

60. Although the conseiller (sector leader) of Masaka at that time has not been accused of orchestrating genocide crimes, some cell-level leaders have been implicated. In various other places across the country, sector and cell-level leaders have been accused of taking leadership roles in the killings in their areas.

61. Interview \#26 (male Hutu).

62. Mironko, "Ibitero."

63. Chantal has carefully preserved the letter containing the "promise," signed by the leaders of that mob. When the piece of paper began to tear at the folds, she photocopied it, and later she introduced it as evidence in a trial. 